\title{
Comparative Morphology, Respiration, and Phagocytic Function of Leukocytes from Blood and Joint Fluid in Rheumatoid Arthritis*
}

\author{
Phyllis T. Bodel † and J. W. Hollingsworth \\ (From the Department of Internal Medicine, Yale University School of Medicine, \\ New Haven, Conn.)
}

Knowledge of leukocyte function in man is derived almost entirely from white cells obtained from blood. In animals, however, most experimental work on granulocytes has been carried out with cells from peritoneal exudates produced by a variety of inflammatory stimuli. Alterations in the metabolism of leukocytes after migration from the blood stream to areas of inflammation have been described (1-3). Since polymorphonuclear leukocytes characteristically perform their most important function at extravascular sites, studies of human leukocytes from an inflammatory exudate would be of interest.

Synovial effusions from patients with rheumatoid arthritis provide an excellent source for exudate leukocytes. In this study, leukocytes from the blood and joint fluid of patients with rheumatoid arthritis were compared in vitro with regard to morphology, viability, respiration, and phagocytic capacity for Staphylococcus aureus.

\section{Methods}

All glassware used was sterilized at $160^{\circ} \mathrm{C}$ for 2 hours to inactivate endotoxin. Krebs-Ringer phosphate buffer, $\mathrm{pH} 7.4$, modified to contain one-fifth the usual concentrations of $\mathrm{CaCl}_{2}$ and $\mathrm{MgSO}_{4}$, was sterilized by autoclaving at 15 pounds pressure for 2 hours.

Patients. Studies were performed on blood and joint fluid from 18 patients with rheumatoid arthritis. Diagnostic criteria of classical or definite rheumatoid arthritis as defined by the American Rheumatism Association were used. All patients were ambulatory or undergoing short hospitalizations. Therapy at the time of study was variable. Nine patients had no medication or were

* Submitted for publication June 11, 1965 ; accepted December 27, 1965.

Supported in part by a grant for arthritis research from the John A. Hartford Foundation and by a grant (AM-07348) from the U. S. Public Health Service.

$\dagger$ Address requests for reprints to Dr. Phyllis T. Bodel, Yale University School of Medicine, 333 Cedar St., New Haven, Conn. on aspirin alone. Four were receiving prednisone, 5 to $10 \mathrm{mg}$ per day, and the other five were receiving several medications, including gold and hydroxychloroquine. No patients were suspected of having intercurrent infections, and none were receiving antibiotics.

Preparation of leukocytes. Sterile siliconized syringes containing 1 to $2 \mathrm{mg}$ of heparin per $10 \mathrm{ml}$ of fluid were used to collect blood from the antecubital vein and joint fluid from the knee. Shoulder fluid was used in one experiment. Joint fluid was filtered through several layers of sterile gauze to remove fibrin clumps. The blood was allowed to settle at room temperature for $\frac{1}{2}$ to 1 hour to obtain a plasma layer.

For preparation of "whole fluids," the joint fluid or plasma was centrifuged at 5 to $20^{\circ} \mathrm{C}$ at $1,500 \mathrm{rpm}$ in an International no. 2 centrifuge for 15 to 20 minutes. It was found that clumping was markedly reduced when cells were processed at 15 to $20^{\circ} \mathrm{C}$, and all later experiments were done at these temperatures. Some supernatant fluid was removed, and the cells were gently resuspended to adjust the concentration of polymorphonuclear leukocytes to about $3 \times 10^{7}$ per $\mathrm{ml}$. For preparation of washed cells, portions of joint fluid or plasma were centrifuged as above, the supernatant was removed, and the cells were resuspended in $40 \mathrm{ml}$ of Krebs-Ringer phosphate buffer containing $2 \mathrm{mg}$ heparin per $10 \mathrm{ml}$. After centrifugation, the cells were resuspended in a small volume of heparinized buffer to maintain the same concentration of polymorphonuclear leukocytes as for the whole fluids. Differential counts were performed on all fluids. In plasma preparations, one to five erythrocytes per leukocyte and 250,000 to 750,000 platelets per $\mathrm{mm}^{8}$ were usually present. Joint fluids containing more than $5 \%$ monocytes were excluded. All transfers of cells, plasma, and joint fluid in each experiment were autologous.

Bacteria. Staphylococcus aureus, phage type 80-81, was used throughout. The characteristics of this strain have been previously described (4). The culture was kept on a blood agar plate at $2^{\circ} \mathrm{C}$ and subcultured every 3 to 4 weeks. For each experiment an 18-hour growth of this strain in beef heart infusion broth was centrifuged, washed once with saline, and the bacterial cells resuspended in a constant volume of buffer containing $0.1 \%$ bovine serum albumin. This preparation contained consistently $1.2 \times 10^{\circ}$ bacteria per ml.

Incubation. Incubation was carried out in standard Warburg flasks at a temperature of $37.5^{\circ} \mathrm{C}$ for 2 hours. 
Manometer joints were wiped with alcohol just before use, and sterile cotton balls were inserted lightly into the joint. Flasks contained $0.2 \mathrm{ml} 15 \%$ potassium hydroxide in the center well with a filter paper fan. In the main compartment was placed $1 \mathrm{ml}$ of the leukocyte suspension containing approximately $3 \times 10^{7}$ leukocytes, either as whole fluid or washed cells in buffer, and either $1.6 \mathrm{ml}$ of buffer (when whole fluid was used) or $0.6 \mathrm{ml}$ buffer with $1 \mathrm{ml}$ of cell-free joint fluid or plasma (when washed cells were used). The cell-free joint fluid and plasma were prepared by centrifugation at $3,000 \mathrm{rpm}$ at $2^{\circ} \mathrm{C}$ for 20 minutes. The flask sidearm contained $0.2 \mathrm{ml}$ of the suspension of 80-81 staphylococci (containing about $2 \times$ $10^{8}$ bacteria). After equilibration for 20 minutes, manometer readings were taken at 15 -minute intervals. After about 1 hour, the contents of the sidearms were added to the main flask, and incubation with bacteria was carried out for 1 hour. Control flasks in each experiment included a thermobarometer and flasks containing cell-free joint fluid or plasma with buffer and staphylococci. To prevent clotting of plasma during the 2-hour incubation, a total of $0.35 \mathrm{mg}$ heparin per $\mathrm{ml}$ was found to be needed and was included in all flasks.

Quantitation of phagocytosis. The method of Cohn and Morse (5) was used to enumerate total, supernatant, and cell-associated live bacteria in the flasks at the end of the experiment. Samples were centrifuged at $2^{\circ} \mathrm{C}$ and kept in ice if not plated at once. All samples were homogenized, 100-fold dilutions in saline were made, and pour plates prepared. Staphylococcal colonies on the pour plates were counted after overnight incubation. In each experiment, the staphylococcal inoculum, the thermobarometer, and the control flasks containing staphylococci with plasma or joint fluid supernatant were counted. Usually the values for supernatant plus cell-associated staphylococci equaled 70 to $95 \%$ of the value obtained from the sample representing total live staphylococci per flask.

Data. Duplicate flasks were used in as many instances as possible (half of reported values). Experiments in which technical difficulties prevented adequate evaluation of data were excluded. These included incubations in which the plasma or joint fluid showed evidence of clotting, experiments where results from duplicate flasks were inconsistent, and experiments where the numbers of polymorphonuclear leukocytes in the flask were less than $2 \times 10^{7}$ or more than $4.5 \times 10^{7}$. In an occasional experiment ( 3 of the first 20 ), bactericidal activity of both plasma and joint fluid was apparent, in that 60 to $95 \%$ of the bacteria added to the cell-free fluids were killed at the end of the incubation period. These experiments were also omitted.

Eosin counts. Eosin counts were performed on whole and washed leukocytes by the method of Hanks and Wallace (6). Two hundred white cells were counted in each determination.

Thin preparations for morphology. A sterile slide was placed on moist filter paper in a petri dish. A drop of joint fluid or plasma was covered with a sterile coverslip and incubated for 20 minutes at $37^{\circ}$. The coverslip was gently removed from the slide, quickly dried with compressed air, and stained with Wright's stain, as described by Hirsch and Cohn (7).

Antibody assay. Blood and joint fluid antibody titers against antigens in 80-81 staphylococcal broth culture filtrate were determined by a method previously described (8). Washed sheep red cells were incubated with 80-81 broth filtrate for 2 hours and then washed and suspended in saline. Portions were added to serial twofold dilutions of plasma, serum, or joint fluid that had been previously absorbed with normal sheep cells. Hemagglutinin titers were read at 24 hours. Plasma or serum and joint fluid supernatants of nine patients were studied. Some fluids had been stored at $-20^{\circ} \mathrm{C}$ for several months.

\section{Results}

Viability and morphology of leukocytes. Leukocytes from joint fluid were often more easily damaged by the isolation procedures than were plasma leukocytes. Although plasma white cells could be repeatedly washed in buffer, joint fluid leukocytes frequently disintegrated after several washes. In these experiments, therefore, only one wash with buffer was carried out routinely.

Examination of Wright's stain preparations indicated that among joint fluid leukocytes there were usually a few cells with pycnotic or highly subdivided nuclei. These were rarely seen in preparations of plasma.

Exclusion of eosin dye has been used as a sensitive measure of cell viability (6). Eosin counts of leukocytes from blood and joint fluid indicated no difference in the numbers of viable cells in each preparation. When the fluids from six patients were examined, there were $1 \%$ eosin-positive cells in joint fluid of three, and less than $1 \%$ in the joint fluid from the other three; all plasma leukocytes were less than $1 \%$ positive. After a single wash, eosin-positive cells in both plasma and joint fluid preparations varied from 0 to $6 \%$.

When thin preparations were made, joint fluid polymorphonuclear leukocytes from many patients were seen to be strikingly vacuolated and degranulated (see Figure 1, B, C, and D). Paired slides of leukocytes from joint fluid and plasma of rheumatoid arthritis patients were examined by one of us with labels obscured. Vacuolization and degranulation of 50 to 100 consecutive, well-preserved granulocytes were estimated at 0 to $4+$. An average score was then calculated for each leukocyte preparation. No plasma preparations 
had ratings over $1+$ (see Figure 1, A), whereas 13 of 21 joint fluid preparations showed 2 to $4+$ changes. A correlation was noted between the presence of a positive serum latex or sheep cell titer and morphologic abnormalities of leukocytes from joint fluid (see Table I). Six patients in the series were seronegative, including two with juvenile rheumatoid arthritis; none had leukocyte changes greater than $2+$. In contrast, 11 of 15 seropositive patients showed 3 or $4+$ changes. The titer of serum rheumatoid factor also appeared related to the degree of cell alteration. All four seropositive patients showing minimal cell changes had sheep cell and latex titers less than 160 . In contrast, 9 of 11 seropositive patients with 3 to $4+$ changes had one or both of these titers equal to or greater than 160 .
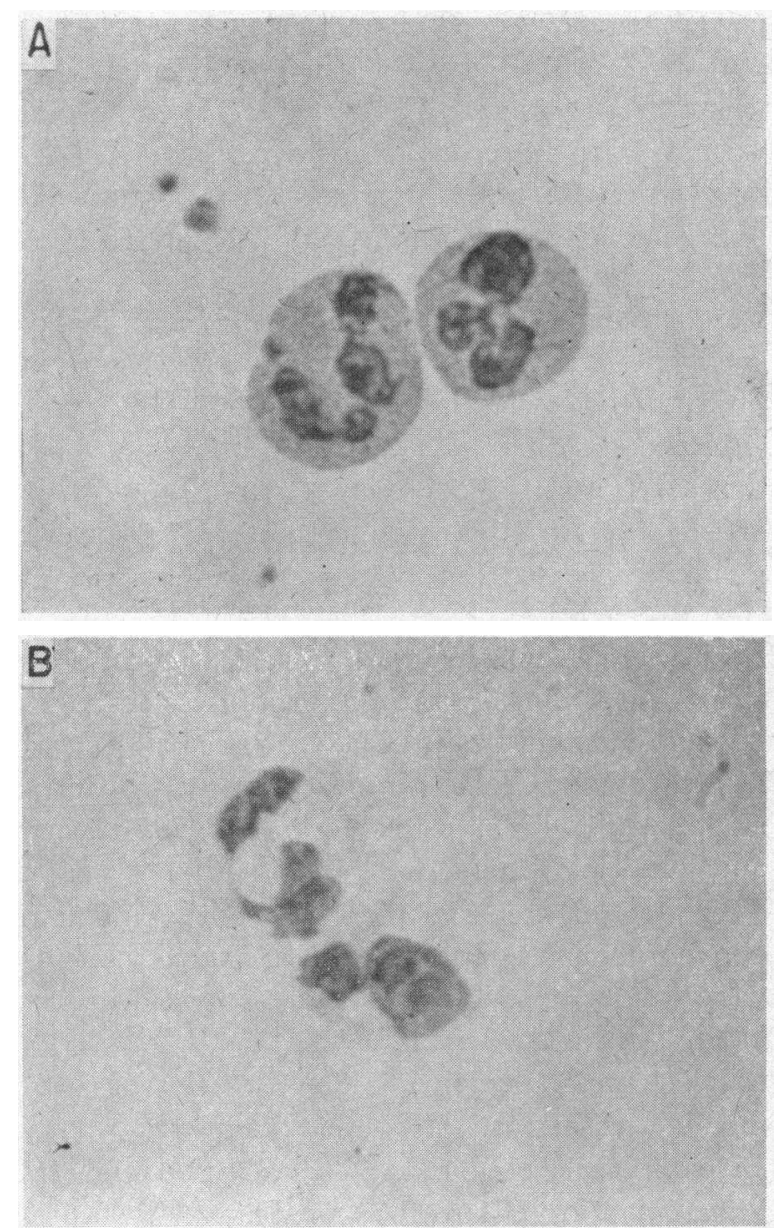

Fig. 1. Polymorphonuclear leukocytes from patients with RheUmatoid arthritis. A) Normal granulocytes from blood. B, C, D) Joint fluid cells showing extensive degranulation (B), partial degranulation with vacuolization (C), and extensive vacuolization with minimal degranulation (D).
Attempts to correlate abnormalities of leukocyte appearance with rates of respiration were not successful in a small series. Joint fluid leukocytes with minimal morphologic changes, obtained from three patients, had an average respiration of $9 \mu 1$ per hour, compared to an average of $12 \mu \mathrm{l}$ per hour for cells that had 2 to $4+$ changes, obtained from six patients. Numbers of leukocytes were similar in both experimental groups.

On four occasions, washed plasma leukocytes were added to cell-free joint fluid, incubated for 2 to 3 hours, and then examined morphologically. Patients whose joint fluid leukocytes were extensively vacuolated and degranulated were selected. In no experiment were significant morphologic changes observed in the plasma polymorphonuclear leukocytes after incubation. Oc-
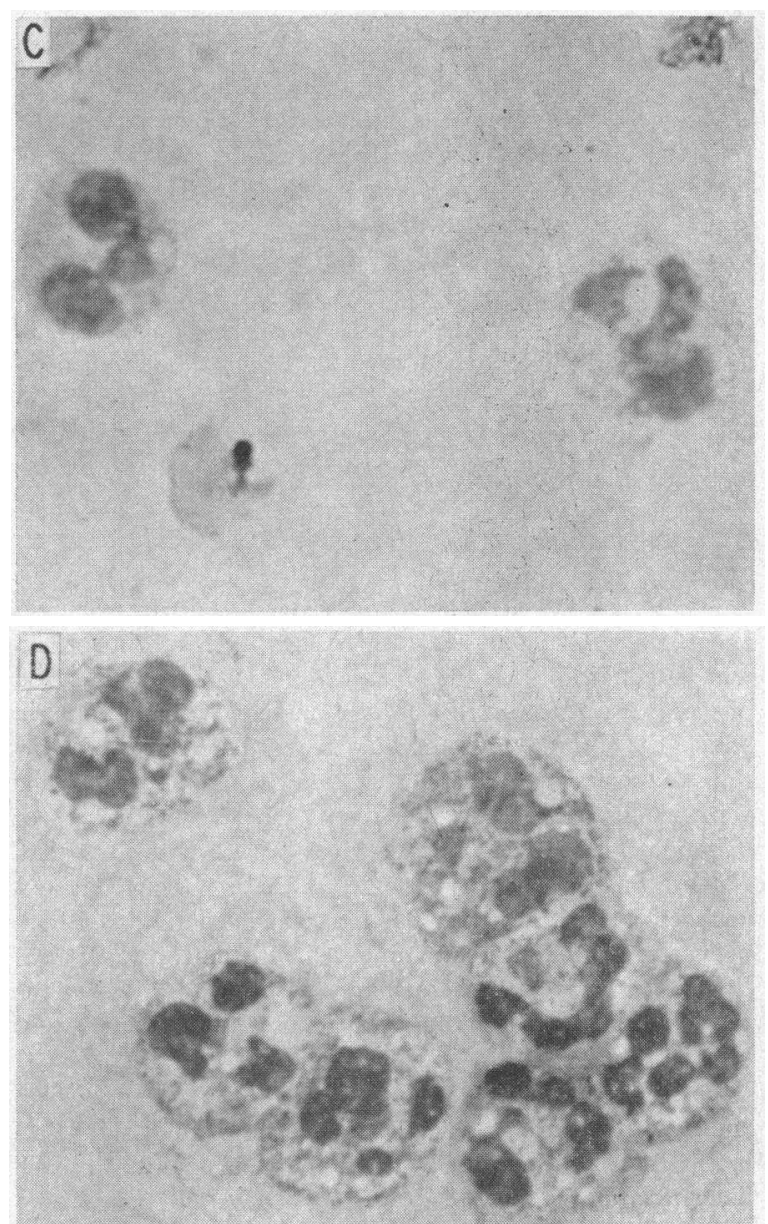
TABLE I

Vacuolization and degranulation of leukocytes from joint fluid

\begin{tabular}{ccccccc}
\hline & \multirow{2}{*}{$\begin{array}{c}\text { No. of } \\
\text { patients }\end{array}$} & $\begin{array}{c}\text { Titer of } \\
\text { rheumatoid } \\
\text { factor* }\end{array}$ & \multicolumn{4}{c}{ Degree of morphologic changet } \\
\cline { 3 - 7 } & 0 & $1+$ & $2+$ & $3+$ & $4+$ \\
\hline 6 & Negative & 1 & 3 & 2 & & \\
6 & $<160$ & 1 & 3 & & 2 & 5 \\
9 & $>160 \ddagger$ & & & & 4 & 5
\end{tabular}

* Sheep cell agglutination and latex fixation titers.

$\dagger$ Average of values for 50 to 100 leukocytes per patient (see text).

$\ddagger$ Titers of one or both tests equaled or exceeded 160 .

casionally a granulocyte contained one or two large vacuoles; this occurred after incubation in both plasma and joint fluid. No increase in respiration of leukocytes from plasma was ever observed during incubation in joint fluid.

Respiration. Respiration of leukocyte preparations from joint fluid was strikingly lower than that of plasma leukocyte preparations from the same patient, as shown in Table II. Data from six consecutive patients are presented. Although numbers of polymorphonuclear leukocytes were approximately equal in both media, the respiration of cells in whole joint fluid was less than half that of cells in whole plasma. Results obtained by others indicate that platelets (9) and red cells (10), which were also present in plasma preparations, are not responsible for this difference. Two experiments in which $5 \times 10^{8}$ to $1 \times 10^{9}$ platelets were incubated in our system corroborated this; the respiration was too low to measure.

This difference in respiration of leukocytes from joint fluid and plasma was also observed when the

TABLE II

Respiration of leukocyte preparations from plasma and joint fluid

\begin{tabular}{|c|c|c|c|c|}
\hline \multirow[b]{2}{*}{ Patient } & \multicolumn{2}{|c|}{ Joint fluid } & \multicolumn{2}{|c|}{ Plasma } \\
\hline & PMN* & $\mathrm{O}_{2}$ uptaket & PMN* & $\mathrm{O}_{2}$ uptakef \\
\hline & & $\begin{array}{l}\text { ul/hour/ } \\
\text { flask }\end{array}$ & & $\begin{array}{l}\text { ml/hour/ } \\
\text { flask }\end{array}$ \\
\hline$Q$ & 4.5 & 10 & 3.0 & 27 \\
\hline B & 3.5 & 4 & 3.5 & 20 \\
\hline $\mathrm{K}$ & 3.8 & 13 & 4.0 & 26 \\
\hline $\mathbf{R}$ & 3.0 & 7 & 3.0 & 20 \\
\hline $\mathrm{O}$ & 5.0 & 11 & 3.0 & 29 \\
\hline $\mathbf{S}$ & 3.0 & 18 & 3.2 & 30 \\
\hline Mean & $\begin{array}{l}3.8 \\
\mathrm{p}<0.01\end{array}$ & $10.5 \pm 2.0 \ddagger$ & 3.3 & $25.3 \pm 1.8$ \\
\hline
\end{tabular}

* Total polymorphonuclear leukocytes per flask $\times 10^{7}$.

$\dagger$ Average of daplicate or triplicate flasks. Flasks contained in the main compartment $1.0 \mathrm{ml}$ plasma or joint fluid and $1.6 \mathrm{ml} \mathrm{Krebs}$ Ringer phosphate buffer.

$\ddagger$ Standard error of mean.
TABLE III

Respiration of washed leukocytes

\begin{tabular}{|c|c|c|c|c|}
\hline $\begin{array}{l}\text { Leukocyte } \\
\text { source }\end{array}$ & $\begin{array}{l}\text { No. of } \\
\text { patients }\end{array}$ & $\begin{array}{l}\text { Suspending } \\
\text { medium }\end{array}$ & PMN* & $\mathrm{O}_{2}$ uptake \\
\hline & & & & $\begin{array}{l}\mu l / \text { hour/ } \\
\text { flask }\end{array}$ \\
\hline Joint fluid (7) $\ddagger$ & 6 & Plasma & 2.8 & $10.9 \pm 1.8 \S$ \\
\hline Plasma (7) & 7 & Joint fluid & 2.0 & $\begin{array}{l}23.7 \pm 2.4 \\
p<0.01\end{array}$ \\
\hline
\end{tabular}

* Average polymorphonuclear leukocytes per flask $\times 10^{7}$

† Average of duplicate flasks. Flasks contained in the main compartment $1.6 \mathrm{ml}$ Krebs-Ringer phosphate buffer, washed leukocytes, and $1.0 \mathrm{ml}$ plasma or joint fluid supernatant.

$\neq$ Figures in parentheses indicate number of experiments.

$\$$ Figures in parentheses ind
Standard error of mean.

cells were washed and suspended in the opposite fluid from the same patient (see Table III). Average values for respiration of joint fluid leukocytes incubated in plasma are less than half those for plasma leukocytes incubated in joint fluid. Also, in nearly all experiments, the respiration of leukocytes from the same source was nearly identical regardless of the suspending medium, as illustrated in the first part of the curve in Figure 2.

When staphylococci were added from the sidearm, both joint fluid and plasma leukocytes showed an increase in oxygen consumption with phagocytosis (see Figure 2). This increase appeared similar in most experiments. However, the ex-

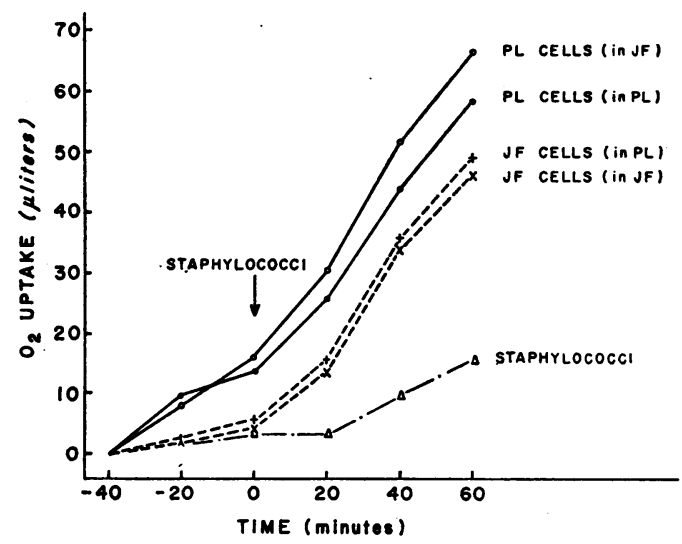

Fig. 2. Respiration of cells from joint fluid (JF) AND PLASMa (PL) OF a PATIENT WITH RHEUMATOID ARTHRITIS. Flasks contained 3.0 to $4.5 \times 10^{7}$ polymorphonuclear leukocytes suspended in $1.0 \mathrm{ml}$ plasma or joint fluid cell-free supernatant, plus $1.6 \mathrm{ml}$ Krebs-Ringer phosphate buffer in the main chamber and $0.2 \mathrm{ml} 15 \% \mathrm{KOH}$ in the center well. Live staphylococci $\left(2.0 \times 10^{8}\right)$ were tipped into the main chamber at zero time. In two flasks, the staphylococci were added to $1.6 \mathrm{ml}$ buffer and $1.0 \mathrm{ml}$ cell-free plasma or joint fluid. The lines represent averages of duplicate flasks. 
act increment in oxygen consumption of the leukocytes alone could not usually be determined, since the oxygen uptake of staphylococci in cell-free plasma or joint fluid was frequently about $20 \mu \mathrm{l}$ per hour. In three similar experiments, however, in which the respiration of the bacteria was negligible (less than $7 \mu$ l of oxygen per hour), the average increase in oxygen consumption of joint fluid was $27 \mu$ l per hour, compared to an increase of $34 \mu \mathrm{l}$ for preparations of blood leukocytes. Furthermore, in one experiment (Figure 3), heat-killed staphylococci were added to flasks containing whole plasma or whole joint fluid in a ratio of about 10 bacteria per leukocyte. Increased respiration occurred in all flasks containing cells after bacteria were added, although the response in the joint fluid flasks was delayed. After 20 minutes, the respiration of both leukocyte preparations was similar for the remainder of the experiment ( $29 \mu \mathrm{l}$ for joint fluid compared to 36. $\mu$ l for plasma).

Phagocytosis. When 80-81 staphylococci were added to whole joint fluid or whole plasma containing similar numbers of granulocytes, less phagocytosis appeared to take place in joint fluid (see Table IV). More live staphylococci were present in the supernatants of the joint fluid flasks, as well as more total live bacteria per flask. These values appear to reflect diminished phagocytosis of bacteria by the leukocytes in whole joint fluid compared with the leukocytes in whole plasma. ${ }^{1}$

1 There was frequently some bactericidal activity in samples of cell-free plasma and joint fluid. Although this activity was on the average greater in plasma, it did not appear to explain the consistently greater loss of

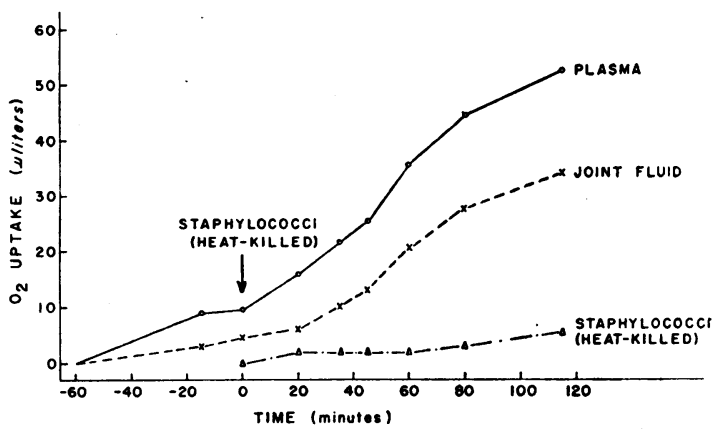

Fig. 3. Respiration of JOINT FLUid AND PLASMa PREPARATIONS FROM A PATIENT WITH RHEUMATOID ARTHRITIS. Flasks contained plasma or joint fluid with 3.2 to $3.5 \times 10^{7}$ polymorphonuclear leukocytes, $1.6 \mathrm{ml}$ KrebsRinger phosphate buffer, and $0.2 \mathrm{ml} 15 \% \mathrm{KOH}$ in the center well. About $3 \times 10^{3}$ heat-killed staphylococci were tipped into the main flask at zero time. In two flasks, heat-killed bacteria were added to $1.6 \mathrm{ml}$ buffer and $1.0 \mathrm{ml}$ cell-free joint fluid or plasma. Values for respiration represent averages of triplicate flasks of cell preparations and duplicate flasks of bacteria.

There was no significant difference in the numbers of cell-associated live bacteria. This finding suggests that the intracellular destruction of ingested bacteria proceeded similarly in both types of leukocytes.

It was clearly of interest to determine whether the diminished phagocytosis in joint fluid was due to differences in the leukocytes or the cell-free fluid or both. To investigate the role of the incubation medium, we washed leukocytes from

bacteria from the supernatants of flasks containing plasma with white cells. Thus, in four experiments from Table IV in which cell-free joint fluid had equal or greater bactericidal activity than plasma, measurements of phagocytosis in plasma all exceeded those in joint fluid.

TABLE IV

Phagocytosis of staphylococci by leukocytes from joint fluid and plasma

\begin{tabular}{|c|c|c|c|c|c|c|c|}
\hline \multirow[b]{2}{*}{ Leukocyte source } & \multirow{2}{*}{$\begin{array}{l}\text { No. of } \\
\text { patients }\end{array}$} & \multirow[b]{2}{*}{ PMN* } & \multirow{2}{*}{$\begin{array}{l}\text { No. of } \\
\text { staph } \\
\text { added } †\end{array}$} & \multicolumn{3}{|c|}{ Live staph af ter phagocytosis $\dagger$} & \multirow{2}{*}{$\begin{array}{l}\text { Live staph in } \\
\text { control flask }\end{array}$} \\
\hline & & & & Total & ratant & Cell-associated & \\
\hline Whole joint fluid (9)§ & 8 & 3.3 & 20.3 & $\begin{array}{c}9.5 \\
\pm 2.0 \|\end{array}$ & $\begin{array}{r}4.2 \\
\pm 1.3\end{array}$ & $\begin{array}{c}3.9 \\
\pm 0.73\end{array}$ & $\begin{array}{l}22.7 \\
\pm 0.26\end{array}$ \\
\hline \multirow[t]{2}{*}{ Whole plasma (8) } & 6 & 2.8 & 20.0 & 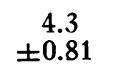 & $\begin{array}{r}0.70 \\
\pm 0.09\end{array}$ & $\begin{array}{c}3.1 \\
\pm 0.78\end{array}$ & $\begin{array}{l}17.0 \\
\pm 0.06\end{array}$ \\
\hline & & & & $\mathrm{p}<0.05$ & $\mathrm{p}<0.05$ & & $\mathrm{p}<0.2$ \\
\hline
\end{tabular}

* Average polymorphonuclear leukocytes per flask $\times 10^{7}$.

$\dagger$ Average per flask $\times 10^{7}$.

$\neq$ Control flask contains buffered cell-free fluid and staphylococci.

$\S$ Figures in parentheses indicate number of experiments.

Standard error of mean. 
TABLE V

Effect of incubation medium on phagocytosis by leukocytes from joint fluid and plasma

\begin{tabular}{|c|c|c|c|c|c|}
\hline \multirow[b]{2}{*}{ Leukocyte source } & \multirow{2}{*}{$\begin{array}{c}\text { No. of } \\
\text { patients }\end{array}$} & \multirow[b]{2}{*}{ PMN* } & \multirow{2}{*}{$\begin{array}{l}\text { No. of } \\
\text { staph } \\
\text { added } t\end{array}$} & \multicolumn{2}{|c|}{ Live staph in supernatant af ter phagocytosis $\dagger$} \\
\hline & & & & Joint fluid medium & Plasma medium \\
\hline $\begin{array}{l}\text { Joint fluid (10)‡ } \\
\text { Plasma (9) }\end{array}$ & $\begin{array}{l}8 \\
6\end{array}$ & $\begin{array}{l}3.2 \\
2.3 \\
\text { Medium } \\
\text { alone }\end{array}$ & $\begin{array}{l}20.4 \\
20.8 \\
20.6\end{array}$ & $\begin{array}{l}3.01 \pm 0.47 \S \\
2.38 \pm 0.56 \\
23.4 \pm 0.17 \\
(13)\end{array}$ & $\begin{array}{l}0.84 \pm 0.19 p<0.01 \\
0.73 \pm 0.15 p<0.02 \\
17.8 \pm 0.12 p<0.05 \\
(14)\end{array}$ \\
\hline
\end{tabular}

* Average polymorphonuclear leukocytes per flask $\times 10^{7}$.

$\dagger$ Average per flask $\times 10^{7}$

$\ddagger$ Figures in parentheses indicate number of experiments.

$\$$ Standard error of mean.

either joint fluid or plasma once, resuspended them in buffer, and incubated them in autologous cell-free plasma and joint fluid. Since sufficient numbers of leukocytes from both sources were not always available in each patient, two groups of experiments are presented in Table V. The upper half of the Table shows the effect of the incubation medium on phagocytosis of staphylococci by leukocytes from joint fluid of eight patients; the lower half is a comparable experiment with plasma leukocytes from a different group of six patients. Plasma medium permitted more phagocytosis by both joint fluid and plasma leukocytes than did the joint fluid medium, as determined by the numbers of live bacteria remaining in the flask supernatant fluid after incubation. The bactericidal activity of cell-free plasma in these experiments is similar to that which has been described previously (see footnote 1). It appears, then, that leukocytes from either joint fluid or plasma are capable of greater phagocytosis in plasma than in joint fluid.

The decrease in phagocytic capacity of whole joint fluid compared to whole plasma (shown in Table IV) appears, then, to be largely explained by differences between joint fluid and plasma media (shown in Table V). However, there was considerable variation in phagocytic activity of cells from the different patients included in the experiments in Table V. Because of this variation, it was possible that a subtle difference in phagocytic ability of cells from joint fluid and blood of any single patient might have been overlooked. To investigate this possibility, we obtained cells from both plasma and joint fluid from the same patient, washed them once, and incubated samples of cells from each source with either cellfree joint fluid or plasma from that patient. These experiments are presented in Table VI. When incubated in joint fluid, plasma leukocytes showed a somewhat greater phagocytic capacity $(p=<0.05)$ than did joint fluid cells from the same patient (see upper half of Table VI). Leukocyte preparations from both sources, however, when incubated in plasma showed similar phagocytic ability (see lower half of Table. VI). In these experiments, then, little evidence was obtained for a difference in phagocytic capacity of cells from blood and joint fluid.

TABLE VI

Effect of leukocyte source on phagocytosis in joint fluid and plasma

\begin{tabular}{|c|c|c|c|c|c|}
\hline \multirow[b]{2}{*}{ Medium } & \multirow{2}{*}{$\begin{array}{l}\text { No. of } \\
\text { patients }\end{array}$} & \multirow{2}{*}{$\begin{array}{l}\text { Staph } \\
\text { added* }\end{array}$} & \multicolumn{3}{|c|}{ Live staph in supernatant* } \\
\hline & & & Medium alone & Plasma leukocytes & Joint fluid leukocytes \\
\hline Joint fluid (8) $†$ & 8 & 21.8 & $24.7 \pm 0.06$ & $\begin{array}{l}2.15 \pm 0.73 \ddagger \\
(2.6) \S\end{array}$ & $\begin{array}{l}5.15 \pm 1.30 \mathrm{p}<0.05 \\
(2.8) \S\end{array}$ \\
\hline Plasma (6) & 5 & 19.8 & $17.8 \pm 0.06$ & $\begin{array}{l}0.49 \pm 0.01 \\
(2.4) \S\end{array}$ & $\begin{array}{l}0.54 \pm 0.01 \\
(2.6) \S\end{array}$ \\
\hline
\end{tabular}

* Average per flask $\times 10^{7}$.

$\dagger$ Figures in parentheses indicate number of experiments.

† Standard error of mean.

$\$$ Average polymorphonuclear leukocytes per flask $\times 10^{7}$. 
TABLE VII

Titer* of antibody to staphylococcal broth filtrate antigens

\begin{tabular}{lrr}
\hline Patient & Joint fluid & $\begin{array}{c}\text { Plasma or } \\
\text { serum }\end{array}$ \\
\hline O'S & 64 & 128 \\
K & 128 & 128 \\
H & 4 & 8 \\
R & 8 & 16 \\
T & 16 & 32 \\
O & 16 & 32 \\
D & 8 & 8 \\
S & 32 & 64 \\
B & 64 & 64
\end{tabular}

* Reciprocal of highest dilution with $1+$ hemagglutinin.

Antibody studies. Since phagocytosis of some strains of Staphylococcus aureus is enhanced by the presence of strain-specific antibody (5), a determination was made of antibody titers in cellfree plasma and joint fluid to antigens present in 80-81 staphylococcal broth culture filtrate. The particular antigens that normal sheep cells adsorb and to which antibody titers were determined have not been clearly defined, but they probably include an antigen common to several gram-positive organisms (11), as well as an antigen specific to the staphylococcus (12). Plasma and joint fluid supernatants of nine patients were studied. Antibody titers are given in Table VII. Although in most cases joint fluid antibody levels were slightly lower than those in plasma, antibody against antigens present in 80-81 staphylococcal filtrate was demonstrated in both fluids. Several reports have indicated that the protein content of rheumatoid arthritis joint fluid is similar to that of serum, with an equal or slightly lower gamma globulin content $(13,14)$. These observations make it unlikely that differences in antibody levels of serum and joint fluid are responsible for the observed differences in phagocytosis.

\section{Discussion}

The morphological differences between the joint fluid and plasma polymorphonuclear leukocytes observed in these studies included, in many patients, large numbers of joint fluid leukocytes that were vacuolated and extensively degranulated. These cells were viable as measured by the ability of their membranes to exclude a vital dye. In almost all instances, joint fluid cells respired at a lower rate than did similar preparations of plasma leukocytes. The suspending medium clearly did not influence the respiration, and the presence of other blood elements in the plasma preparations does not explain the difference. Platelets suspended in heparinized plasma have been found to have no measurable oxygen consumption (9). The red cells in our preparations ( 1 to $20 \times 10^{7}$ ) are insufficient for measurable respiration (10).

The extent of morphologic changes in joint fluid cells in these few studies did not correlate with the absolute values of oxygen consumption. This finding suggests that low respiration may be a characteristic of exudate granulocytes in these patients. Differences in lactate production between guinea pig circulating and exudate leukocytes have been described $(1,3)$; respiration was not measured. It has been suggested (15) that a decrease in oxidative metabolism is the earliest defect observed in aging or damaged polymorphonuclear leukocytes. Since more than $90 \%$ of the normal leukocyte's energy is derived from glycolysis (16), a defect in oxidative metabolism may be relatively unimportant to cell function. In our experiments, most joint fluid cells appeared to have a normal increase in respiration after phagocytosis. In other granulocytes this increase occurs primarily by way of the hexose monophosphate pathway (17), and is not dependent on the cytochrome system.

Phagocytosis is generally considered a useful indicator of granulocyte function. However, various factors in the suspending medium influence the rate at which cells phagocytize particles (18). The phagocytic capacity of both joint fluid and blood leukocytes for staphylococci was less when these cells were suspended in joint fluid than when they were suspended in plasma. Several factors might be implicated to explain this finding. Levels of complement in most joint fluids are lower than those in serum (19). In rheumatoid arthritis, elevated serum levels and depressed joint fluid levels, compared to normal, have been reported $(19,20)$. Since complement probably enhances phagocytosis of staphylococci $(5,21)$, this difference in complement activity may be an important factor. Staphylococcal antibody titers were not substantially different in the two media. Alterations of the surface properties of leukocytes and bacteria influence phagocytosis (22). Joint fluid components such as hyaluronic acid might impede 
phagocytosis by interfering with cell-particle association. However, in one experiment, treatment of joint fluid with hyaluronidase did not change the phagocytic capacity of the fluid. Furthermore, since phagocytosis does not require exogenous glucose (17), the low levels of glucose present in rheumatoid arthritis effusion (13) do not appear to play a role.

The half-life for granulocytes in effusions of rheumatoid arthritis has been calculated to be less than 6 hours (23). New cells are, therefore, continually entering the joint fluid, either directly from the blood stream or from tissue spaces. However, the observations that joint cells had occasional pycnotic nuclei and low respiration suggest that these cells, though viable and metabolically active, may be an older population than cells obtained from blood. Since the mature polymorphonuclear leukocyte is present in the blood for only a few hours (24), these alterations must develop while the cell resides in extravascular sites.

Ingested aggregates of $19 \mathrm{~S}$ and $7 \mathrm{~S}$ gamma globulin in joint fluid granulocytes, probably representing antigen-antibody complexes, have been reported by Hollander, McCarty, Astorga, and Castro-Murillo and confirmed by Astorga and Bollet $(25,26)$. This phenomenon appears to occur in most rheumatoid arthritis patients, even if rheumatoid factor cannot be demonstrated in the blood. In our series, good correlation was observed between the presence of vacuolization and degranulation and the presence of serum rheumatoid factor as measured by sheep cell and latex agglutination titers. However, when suspended in plasma, these markedly abnormal granulocytes seemed to have a normal phagocytic capacity for staphylococci. Only when suspended in the less effective joint fluid media was a slight deficiency detectable in phagocytic activity of granulocytes from joint fluid, as compared with those from blood. Since materials from the original suspending medium probably remain fixed to the cells after a single washing, this small difference may not represent a true alteration in cell function.

The ingestion of antigen-antibody complexes in vitro by human blood leukocytes is accompanied by increased oxygen consumption (27). When blood leukocytes from patients with rheumatoid arthritis were washed and suspended in joint fluid, however, the respiration of these cells was not al- tered. Furthermore, joint fluid cells with morphologic changes presumably related to phagocytosis of globulin aggregates did not have a greater respiration than did cells without such changes. Finally, incubation of plasma leukocytes for 2 or 3 hours in joint fluid from patients with seropositive arthritis and markedly altered joint fluid cells failed to produce morphologic or respiratory changes in the blood cells.

These experiments make it unlikely that the sequence of events postulated by Hollander and co-workers-phagocytosis of aggregates, degranulation, and release of inflammatory materials-occurs in the joint fluid itself. The same sequence might well occur in the synovial tissue, where rheumatoid factor has been demonstrated by immunofluorescent methods (28). In one critical experiment by Restifo and associates (29), the data seem best fitted to an immunologic event in the synovium rather than in the joint cavity. These investigators injected autologous gamma globulin into the knee joints of patients with rheumatoid arthritis and observed an immediate inflammatory response. However, the characteristic granulocyte inclusions containing $19 \mathrm{~S}$ and $7 \mathrm{~S}$ globulin complexes were not detected in the joint fluid cells until 24 hours later, when the inflammatory reaction actually was subsiding. It is of course possible that other cells in the synovium react to antigen-antibody complexes and take part in the inflammatory response (30). Evidence that might implicate cells other than those in the joint fluid is our observation that several patients with clinically severe arthritis consistently have normally granulated exudate cells.

Polymorphonuclear leukocytes are important in the early defense against staphylococcal disease, as has been shown experimentally in dermal (31), peritoneal (32), and intravenous infections (33). In synovial effusions, particularly in rheumatoid arthritis, the granulocytes are already in the joint fluid and should be capable of rapidly destroying invading staphylococci. However, several clinical reports suggest that inflamed joints are quite frequently a site of secondary staphylococcal invasion (34-36). The observation that joint fluid from patients with rheumatoid arthritis is an unfavorable medium for staphylococcal phagocytosis may in part explain this apparently paradoxical situation. 


\section{Summary}

Leukocytes from blood and joint fluid of 18 patients with rheumatoid arthritis were compared in vitro with regard to morphology, viability, respiration, and phagocytic capacity for Staphylococcus aureus.

Joint fluid granulocytes were frequently vacuolated and degranulated, especially those obtained from patients with demonstrable serum rheumatoid factor. Respiration of joint fluid leukocytes was less than half that of plasma leukocytes, regardless of the medium in which the cells were incubated. These changes in respiration were not correlated with the degree of morphologic change in the joint fluid granulocytes.

Phagocytosis of staphylococci during 1 hour in whole joint fluid was less than that in whole plasma. When washed leukocytes from either source were incubated in cell-free joint fluid and plasma, less phagocytosis occurred in joint fluid medium. Moreover, when suspended in joint fluid, washed joint fluid leukocytes appeared to be less active phagocytes than were plasma leukocytes. This difference in function was not detected, however, when the cells were suspended in plasma.

These observations suggest that differences between the joint fluid and plasma media are primarily responsible for decreased phagocytosis of bacteria by leukocytes in joint fluid. Inefficient phagocytosis of staphylococci in synovial exudate may be a factor in the reported susceptibility of diseased joints to bacterial infection.

\section{Acknowledgment}

We would like to thank Dr. Elisha Atkins for his helpful criticisms and Marcia Abdalla for technical assistance.

\section{References}

1. Hartman, J. D., and M. Reidenberg. Comparison of the glycolytic activity of blood and exudate leucocytes. J. appl. Physiol. 1958, 12, 477.

2. Berlin, R. D., and W. B. Wood, Jr. Molecular mechanisms involved in the release of pyrogen from polymorphonuclear leucocytes. Trans. Ass. Amer. Phycns 1962, 75, 190.

3. Antonioli, J. A. Metabolism of the white blood cell inside and outside the blood stream in Biological Activity of the Leucocyte, Ciba Foundation Study Group No. 10, G. E. W. Wolstenholme and M. O'Connor, Eds. London, J. \& A. Churchill, 1961, p. 92.
4. Atkins, E., and L. R. Freedman. Studies in staphylococcal fever. I. Responses to bacterial cells. Yale J. Biol. Med. 1963, 35, 451.

5. Cohn, Z. A., and S. J. Morse. Interactions between rabbit polymorphonuclear leucocytes and staphylococci. J. exp. Med. 1959, 110, 419.

6. Hanks, J. H., and J. H. Wallace. Determination of cell viability. Proc. Soc. exp. Biol. (N. Y.) 1958, 98, 188 .

7. Hirsch, J. G., and Z. A. Cohn. Degranulation of polymorphonuclear leucocytes following phagocytosis of microorganisms. J. exp. Med. 1960, 112, 1005.

8. Bodel, P. T., and E. Atkins. Studies in staphylococcal fever. IV. Hypersensitivity to culture filtrates. Yale J. Biol. Med. 1964, 37, 130.

9. Campbell, E. W., W. J. Small, and W. Dameshek. Metabolic activity of human blood platelets. J. Lab. clin. Med. 1956, 47, 835.

10. Angelone, L., D. H. Watkins, and C. A. Angerer. Oxygen consumption of erythrocytes from patients with various thyroid conditions related to their respective serum protein-bound iodine concentrations. Blood 1954, 9, 953.

11. Grov, A., B. Myklestad, and P. Oeding. Immunochemical studies on antigen preparations from Staphylococcus aureus. I. Isolation and chemical characterization of antigen A. Acta path. microbiol. scand. 1964, 61, 588.

12. Bodel, P. T., and E. Atkins. Studies in staphylococcal fever. V. Staphylococcal filtrate pyrogen. Yale J. Biol. Med. 1965, 38, 282.

13. Ropes, M. W., and W. Bauer. Synovial Fluid Changes in Joint Disease. Cambridge, Harvard University Press, 1953, pp. 18-77.

14. Wilkinson, M., and B. S. Jones. Serum and synovial fluid proteins in arthritis. Ann. rheum. Dis. 1962, $21,51$.

15. Tullis, J. L. The origin, properties, function and preservation of white blood cells in Blood Cells and Plasma Proteins, J. L. Tullis, Ed. New York, Academic Press, 1953, p. 276.

16. Beck, W. S., and W. N. Valentine. The aerobic carbohydrate metabolism of leucocytes in health and leukemia. I. Glycolysis and respiration. Cancer Res. 1952, 12, 818.

17. Karnovsky, M. L. Metabolic basis of phagocytic activity. Physiol. Rev. 1962, 42, 143.

18. Florey, H. W. Chemotaxis, phagocytosis and the formation of abscesses in General Pathology, $\mathrm{H}$. Florey, Ed. Philadelphia, W. B. Saunders, 1962, p. 98.

19. Pekin, T. J., and N. J. Zvaifler. Hemolytic complement in synovial fluid. J. clin. Invest. 1964, 43, 1372.

20. Fostiropoulos, G., K. F. Austen, and K. J. Bloch. Total hemolytic complement $\left(\mathrm{CH}_{80}\right)$ and second component of complement $\left(\mathrm{C}^{\prime} 2^{\text {hu }}\right)$ activity in serum and synovial fluid. Arthr. and Rheum. 1965, 8, 219. 
21. Austen, K. F., and Z. A. Cohn. Contribution of serum and cellular factors in host defense reactions. I. Serum factors in host resistance. New Engl. J. Med. 1963, 268, 994.

22. Mudd, S., M. McCutcheon, and B. Lucké. Phagocytosis. Physiol. Rev. 1934, 14, 210.

23. Bertino, J. R., J. W. Hollingsworth, and A. R. Cashmore. Granulocyte kinetics in rheumatoid effusions studied by a biochemical label. Trans. Ass. Amer. Phycns 1963, 76, 63.

24. Craddock, C. G. The production, utilization, and destruction of white blood cells in Progress in Hematology. New York, Grune \& Stratton, 1962, vol. 3 , p. 92.

25. Hollander, J. L., D. J. McCarty, Jr., G. Astorga, and E. Castro-Murillo. Studies on the pathogenesis of rheumatoid joint inflammation. I. The "R.A. cell" and a working hypothesis. Ann. intern. Med. 1965, 62, 271.

26. Astorga, G., and A. J. Bollet. Diagnostic specificity and possible pathogenetic significance of inclusions in synovial leucocytes. Arthr. and Rheum. 1965, 8, 511.

27. Strauss, B. S., and C. A. Stetson, Jr. Studies on the effect of certain macromolecular substances on the respiratory activity of the leukocytes of peripheral blood. J. exp. Med. 1960, 112, 653.

28. Mellors, R. C., R. Heimer, J. Corcos, and L. Korngold. Cellular origin of rheumatoid factor. $\mathrm{J}$. exp. Med. 1959, 110, 875.

29. Restifo, R. A., A. J. Lussier, A. J. Rawson, J. H.
Rockey, and J. L. Hollander. Studies on the pathogenesis of rheumatoid joint inflammation. III. The experimental production of arthritis by the intra-articular injection of purified 7S gamma globulin. Ann. intern. Med. 1965, 62, 285.

30. Waksman, B. H. The toxic effects of the antigenantibody reaction on the cells of hypersensitive reactors in Cellular and Humoral Aspects of the Hypersensitive States, H. S. Lawrence, Ed. New York, Hoeber-Harper, 1959, p. 123.

31. Miles, A. A., and J. S. F. Niven. The enhancement of infection during shock produced by bacterial toxins and other agents. Brit. J. exp. Path. 1950, 31, 73.

32. Cohn, Z. A. Determinants of infection in the peritoneal cavity. II. Factors influencing the fate of staphylococcus aureus in the mouse. Yale J. Biol. Med. 1962, 35, 29.

33. Rogers, D. E. Studies on bacteriemia. I. Mechanisms relating to the persistence of bacteriemia in rabbits following the intravenous injection of staphylococci. J. exp. Med. 1956, 103, 713.

34. Kellgren, J. H., J. Ball, R. W. Fairbrother, and K. L. Barnes. Suppurative arthritis complicating rheumatoid arthritis. Brit. med. J. 1958, 1, 1193.

35. Rosin, A. J., and A. Goldberg. Infective complications of rheumatoid arthritis. Scot. med. J. 1962, 7, 296.

36. De Andrade, J. R., and C. R. Tribe. Staphylococcal septicaemia with pyoarthrosis in rheumatoid arthritis. Brit. med. J. 1962, 1, 1516. 